\title{
Activity and dormancy in relation to body water and cold tolerance in a winter-active springtail (Collembola)
}

\author{
WILLIAM BLOCK ${ }^{*}$ and JuERg ZETTEL ${ }^{2}$ \\ ${ }^{1}$ British Antarctic Survey, Natural Environment Research Council, High Cross, Madingley Road, Cambridge CB3 0ET, UK; email: \\ wcb@bas.ac.uk \\ ${ }^{2}$ Zoological Institute, University of Bern, Baltzerstrasse 6, CH-3012 Bern, Switzerland; e-mail: juerg.zettel@zos.unibe.ch
}

Key words. Collembola, Hypogastruridae, winter activity, summer dormancy, body water balance, osmotically inactive water, cold hardiness, Differential Scanning Calorimetry, thermal hysteresis

\begin{abstract}
Ceratophysella sigillata (Collembola, Hypogastruridae) has a life cycle which may extend for $>2$ years in a temperate climate. It exists in two main morphs, a winter-active morph and a summer-dormant morph in central European forests. The winteractive morph often occurs in large aggregations, wandering on leaf litter and snow surfaces and climbing on tree trunks. The summer-dormant morph is found in the upper soil layers of the forest floor. The cryobiology of the two morphs, sampled from a population near Bern in Switzerland, was examined using Differential Scanning Calorimetry to elucidate the roles of body water and the cold tolerance of individual springtails. Mean (SD) live weights were $62 \pm 16$ and $17 \pm 6 \mu \mathrm{g}$ for winter and summer individuals, respectively. Winter-active springtails, which were two feeding instars older than summer-dormant individuals, were significantly heavier (by up to 4 times), but contained less water ( $48 \%$ of fresh weight [or $0.9 \mathrm{~g} \mathrm{~g}^{-1}$ dry weight]) compared with summer-dormant animals ( $70 \%$ of fresh weight [or $2.5 \mathrm{~g} \mathrm{~g}^{-1} \mathrm{dry}$ weight]). Summer-dormant animals had a slightly greater supercooling capacity (mean (SD) $\left.-16 \pm 6^{\circ} \mathrm{C}\right)$ compared with winter-active individuals $\left(-12 \pm 3^{\circ} \mathrm{C}\right)$, and they also contained significantly larger amounts of both total body water and osmotically inactive (unfrozen) water. In the summer morph, the unfrozen fraction was $26 \%$, compared to $11 \%$ in the winter morph. The ratio of osmotically inactive to osmotically active (freezable) water was $1: 1.7$ (summer) and $1: 3.3$ (winter); thus unfrozen water constituted $59 \%$ of the total body water during summer compared with only $30 \%$ in winter. Small, but significant, levels of thermal hysteresis were detected in the winter-active morph $\left(0.15^{\circ} \mathrm{C}\right)$ and in summer-dormant forms $\left(0.05^{\circ} \mathrm{C}\right)$, which would not confer protection from freezing. However, the presence of antifreeze proteins may prevent ice crystal growth when feeding on algae with associated ice crystals during winter. It is hypothesised that in summer animals a small decrease in freezable water results in a large increase in haemolymph osmolality, thereby reducing the vapour pressure gradient between the springtail and the surrounding air. A similar decrease in freezable water in winter animals will not have such a large effect. The transfer of free water into the osmotically inactive state is a possible mechanism for increasing drought survival in the summer-dormant morph. The ecophysiological differences between the summer and winter forms of C. sigillata are discussed in relation to its population ecology and survival.
\end{abstract}

\section{INTRODUCTION}

Mass aggregations of insects and other arthropods occur rarely in winter, but some Collembola form colonies, often in the coldest part of winter (e.g. Uchida \& Fujita, 1968), which behave as superorganisms, moving over the forest floor as entities in a highly synchronised manner. The springtail Ceratophysella sigillata (Collembola, Hypogastruridae) is one such species in European forests (Fig. 1a). It emerges from beneath the snow cover (Fig. 1b), forming dark columns or fronts, which migrate across the snow surface and it also feeds on algae on tree bark in great numbers (Fig. 1c). Few invertebrates exhibit such winter activity followed by a dormant state in summer (e.g. Hågvar, 1995). Two polymorphisms are expressed by $C$. sigillata: an epitoky (reproductive dimorphism) and a seasonal dimorphism, which includes a summer dormancy and surface-active instars during winter (for details of phenology and polymorphisms see Zettel \& Zettel, 1994a, b, 1996). Summer dormancy is triggered by temperature and under natural conditions it is obligatory.

The summer morph remains inactive in the soil from June until late October, the duration of dormancy being controlled by temperature and this is used to synchronise winter activity with season. In experiments using constant thermal conditions (winter), the summer morph and the relative instar were omitted from the developmental cycle (J. Zettel, unpublished). C. sigillata is the only temperate species of Collembola known to have its main growing season during winter, and also the only species with a summer dormancy. Although summer dormancy has been reported for related species under summer drought conditions in the Mediterranean region (eg. Bedos \& Cassagnau, 1988; Cassagnau \& Lauga-Reyrel, 1992), growth is not restricted to the winter season in these species. $C$. sigillata is hygrophilic and requires humid conditions during winter for migration similar to "the snow flea" Isotoma hiemalis (Zettel et al., 1997). Normally it is patchily distributed in the forest floor habitat, and forms dense aggregations or colonies, which move directionally across

\footnotetext{
* Corresponding author.
} 


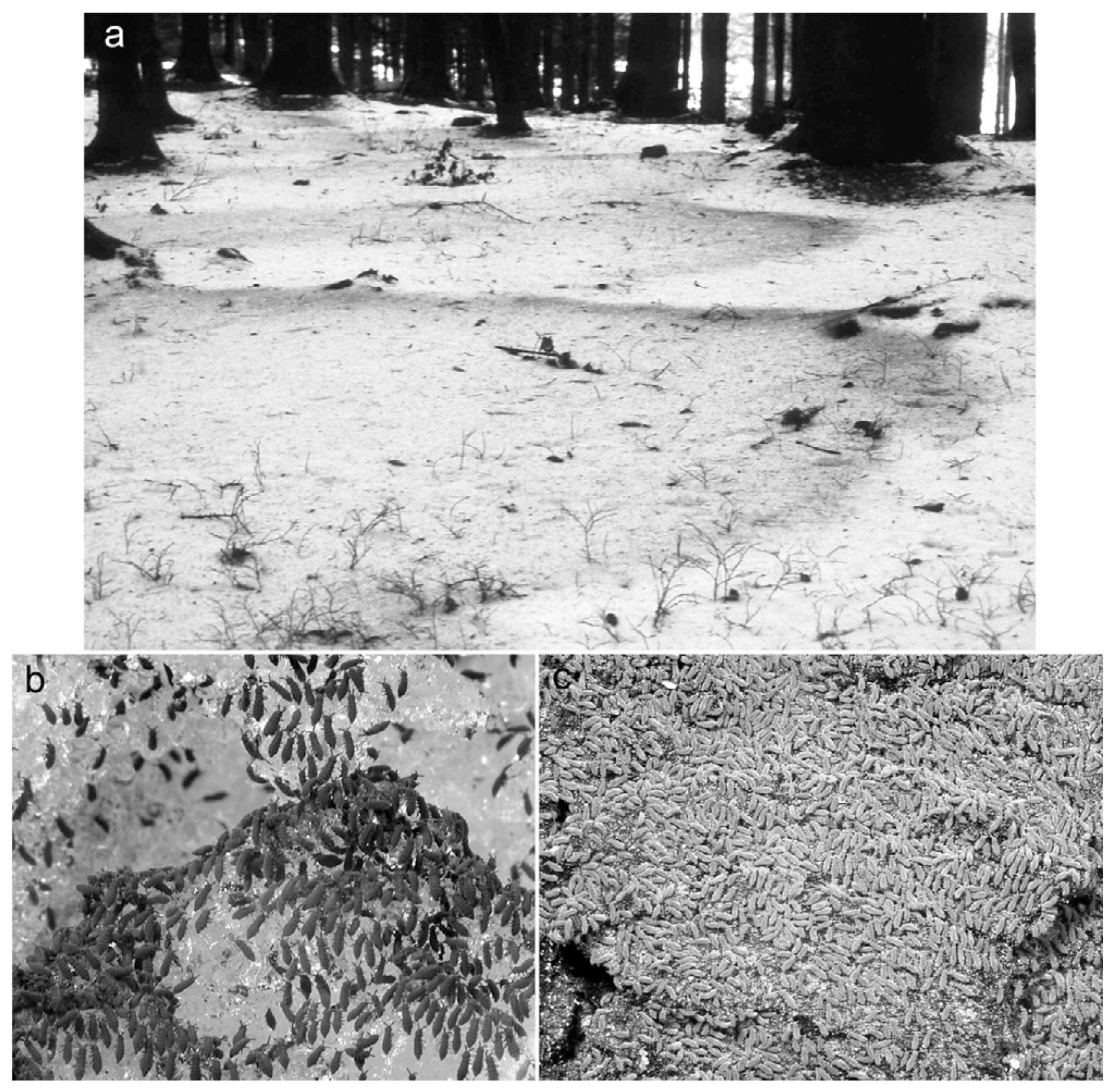

Fig. 1. a - massed colonies of Ceratophysella sigillata moving across the snow surface of the study plot near Bern, Switzerland; $b$ - individuals emerging from the snow before migrating; $\mathrm{c}$ - a monolayer of springtails feeding on algae on tree bark. Body length of mature springtails is $1.5 \mathrm{~mm}$.

the substrate at speeds of up to $1 \mathrm{~m} \mathrm{~h}^{-1}$. The species has well developed jumping and climbing behaviour (Zettel et al., 2000).

These surface colonies are observed in two periods: December to early January and mid-February to midMarch (Zettel \& Zettel, 1994a; Zettel, 1999), and may be band- or sickle-shaped, measuring up to $50 \mathrm{~m}$ or more in width (Fig. 1a). Even without snow cover, the dense colonies, often comprising many millions of individuals, are very conspicuous $\left(1 \mathrm{~m}^{2}\right.$ of densely covered substrate has been estimated to contain $2 \times 10^{6}$ individuals, whereas the largest aggregations comprise $>10^{9}$ individuals). In late winter, the colonies disperse by migrating over considerable distances. Two strategies are found that reduce the risks of such a dispersal pattern. Firstly, aggregation in dense colonies guarantees that the sexes meet even after migration. Secondly, reproduction in two consecutive years may be a risk-splitting strategy when summer drought reduces survival of juveniles during summer dormancy.

Ceratophysella sigillata is dormant during summer and autumn and has its main growing period in winter. During surface activity, individuals feed intensively at temperatures down to $-2.5^{\circ} \mathrm{C}$ on coccal algae covering dead wood on the ground, tree trunks and branches (Suter et al., 1993). All available pieces of dead wood that are covered with algae or fungi are coloured purple due to feeding springtails. They may cover tree trunks to a 
height of several metres above the ground with a purple monolayer of Collembola (Fig. 1c). Feeding reduces their supercooling ability, but if cold-hardened algae are consumed springtail cold hardiness is significantly improved (Zettel et al., 2002). However, the process of sequestration of antifreezes from winter algae is not fully understood.

The aims of the present study were to determine the body water status of the winter-active and summer-dormant morphs, to characterise their cryobiological features and to assess the relation between their freezable and unfreezable water components. The results enable a closer definition of the survival strategy of this species to be made and they attempt to answer the question "Does a winter-active arthropod jeopardise its survival through its unusual life cycle?"

\section{METHODS}

\section{Field sampling and culturing}

Samples of live C. sigillata were collected by hand from a field site (mixed beech-spruce forest) at $640 \mathrm{~m}$ a.s.l., $10 \mathrm{~km}$ north of Bern, Switzerland in March 1997, February 1998, February 2001 (winter-active individuals), and in September 1997, September 1998, August 2001 (summer-dormant individuals). The samples were maintained at $5^{\circ} \mathrm{C}$ with a natural photoperiod for 1-2 days after collection and prior to experimentation in the laboratory, except for some samples when mailed from Bern to Cambridge, UK, which were in culture for $2-3$ weeks. The animals were kept in glass jars with a moist basal layer of plaster of Paris and fed with coccal algae (Stichococcus sp., Klebsorminium sp., Pleurococcus sp.) scraped from tree trunks at the field site.

\section{Water content}

Individual springtails were weighed live in small aluminium containers on a Sartorius M3P microbalance (accuracy $\pm 1 \mu \mathrm{g}$ ) and after air drying at $60^{\circ} \mathrm{C}$ over $24 \mathrm{~h}$ to constant weight to determine their total body water content.

\section{Thermal analysis}

Thermal analysis techniques are widely used in studies of cold resistance and water dynamics of invertebrates (Block, 1994, 2002, 2003). A Differential Scanning Calorimeter (DSC820, Mettler-Toledo) was utilised in this study to examine the thermal changes in individual Collembola subjected to a cooling and warming programme. The DSC system incorporated a heat flux module, a RP100 Intracooler (to $-60^{\circ} \mathrm{C}$ ) and an Epson TAS811 workstation. The system was calibrated using indium (melting point $156.6^{\circ} \mathrm{C}$, enthalpy $28.71 \mathrm{Jg}^{-1}$ ) as an upper temperature and enthalpy standard and dodecane (melting point $-9.65^{\circ} \mathrm{C}$ ) as a lower temperature standard. The melting point of HPLC grade water was used as a calibration check.

Individual collembolans were weighed in sealed $40 \mu 1$ aluminium pans and subjected to the following DSC programme: Cooled from +5 to $-30^{\circ} \mathrm{C}$ at $1^{\circ} \mathrm{C} \mathrm{min}{ }^{-1}$, held isothermally for 1 min at $-30^{\circ} \mathrm{C}$ and re-warmed to $+5^{\circ} \mathrm{C}$ at the same rate. The resultant thermograms were evaluated using $\mathrm{STAR}^{\mathrm{e}}$ software (version 6.0) to provide data on temperatures of freeze onset (supercooling point, SCP), melt onset, melting point (peak temperature of endotherm) and enthalpies of both the freeze and melt transitions. Calculations of the quantity of frozen (osmotically active: $\mathrm{OA}$ ) water in individuals were made using the melt endotherm and the enthalpy value for water $\left(334.5 \mathrm{Jg}^{-1}\right)$ corrected for temperature. OA values were expressed as the propor- tion of total body water which was frozen in particular samples. The amount of osmotically inactive (OI, unfrozen water) was calculated by subtraction of the OA values from the total water content of each insect. The terms "frozen" and "unfrozen" water are used in respect of experimental results in the present study to avoid confusion with "freezable" and "unfreezable" water, which may be different depending upon time, cooling rate and temperature (see Franks, 1986).

\section{Thermal hysteresis}

Using antennal punctures, haemolymph samples (1.2-1.7 nl) were drawn up into glass capillaries (under immersion oil) from freshly-collected individual springtails of the two morphs (23 February 2001 and 22 August 2001, respectively) and their osmolality determined using a Clifton nanolitre osmometer (Zettel, 1984). Measurements were made on haemolymph samples from individual springtails; no pooling of samples was done. The samples were quickly frozen in the osmometer and then warmed at a constant rate of $0.12^{\circ} \mathrm{C} \mathrm{min}{ }^{-1}$ until the last minute ice crystal could be observed at $\times 60$ magnification and the temperature was recorded. Then the samples were cooled at the same rate and the temperature at which ice crystal growth began was noted. The difference between the two temperatures was the freezing point depression (thermal hysteresis). Because the haemolymph droplets were very small, the procedure was repeated on each sample and the values were used only when repeated melting point and freezing point temperatures were obtained. Two controls ( 0 and $1000 \mathrm{mOsm}$ ) were used with each haemolymph sample. The amount of thermal hysteresis was calculated from the osmolal melting point depression of $1.86^{\circ} \mathrm{C}$ Osm $^{-1}$ (Duman, 1977).

\section{Statistical analyses}

Data were analysed using the non-parametric Mann-Whitney $U$ test (software SYSTAT version 7.0).

\section{RESULTS}

\section{Water status}

Individuals of the winter-active morph of C. sigillata sampled from the field were significantly $(P<0.001)$ heavier (up to $4 \times$ ) and contained a greater weight of water (up to $2.5 \times$ ) than those of the summer-dormant morph (Table 1), because they were two (feeding) instars older. However, their relative total water contents, both on fresh and dry weight bases, were reversed; the summer morph having a significantly $(P<0.001)$ higher value $\left(2.5 \mathrm{~g} \mathrm{~g}^{-1}\right.$ dry weight) than winter individuals $\left(0.9 \mathrm{~g} \mathrm{~g}^{-1}\right.$ dry weight). Individual live weights ranged from 5 to $95 \mu \mathrm{g}$ with summer-dormant animals being between 5 (juveniles) and $20 \mu \mathrm{g}$ (adults) and winter-active animals being in the

TABLE 1. Mean (SD) individual body weight and water content of winter-active and summer-dormant morphs of the springtail Ceratophysella sigillata from field samples collected in March 1997 and September 1998, respectively.

\begin{tabular}{lcc}
\hline Parameter & $\begin{array}{c}\text { Winter-active } \\
\text { morph }\end{array}$ & $\begin{array}{c}\text { Summer-dormant } \\
\text { morph }\end{array}$ \\
\hline $\mathrm{n}$ & 46 & 46 \\
Live weight $(\mu \mathrm{g})$ & $62.3(16.2)$ & $17.2(6.4)$ \\
Dry weight $(\mu \mathrm{g})$ & $32.4(8.5)$ & $5.2(2.4)$ \\
Water content & & \\
$\quad$ - live weight $(\%)$ & $48.3(9.1)$ & $69.6(7.6)$ \\
- dry weight $\left(\mathrm{g} \mathrm{g}^{-1}\right)$ & $0.9(0.6)$ & $2.5(1.0)$ \\
\hline
\end{tabular}


TABLE 2. Mean (SD) individual body weight and water content of life stages of the summer-dormant morph of the springtail Ceratophysella sigillata from a field sample collected in September 1998.

\begin{tabular}{lccc}
\hline Parameter & Male & Female & Juvenile \\
\hline $\mathrm{n}$ & 23 & 17 & 6 \\
Live weight $(\mu \mathrm{g})$ & $14.8(3.8)$ & $23.8(2.4)$ & $7.7(2.6)$ \\
Dry weight $(\mu \mathrm{g})$ & $4.3(1.6)$ & $7.6(1.4)$ & $2.2(0.4)$ \\
Water content & & & \\
$\quad-$ live weight $(\%)$ & $70.9(8.2)$ & $67.8(6.6)$ & $70.2(8.5)$ \\
$\quad$ dry weight $\left(\mathrm{g} \mathrm{g}^{-1}\right)$ & $2.7(1.1)$ & $2.2(0.8)$ & $2.5(0.9)$ \\
\hline
\end{tabular}

range 35 to $95 \mu \mathrm{g}$ live weight. For individuals of both morphs, their relative water contents remained stable over their respective live weight ranges.

The developmental stages within the summer-dormant morph differed in mean weight and water content (Table 2 ). The females were heavier than the males and contained a greater weight of water (all by more than $1.5 \times$ ). Juveniles were smaller than either adult stage, but contained a similar weight of water as the males. The relative water content ranged from 68 to $71 \%$ of fresh weight ( 2.2 to $2.7 \mathrm{~g} \mathrm{~g}^{-1}$ dry weight) over the three stages, but the differences were not significant.

\section{Cryobiology}

The main cryobiological characteristics of the two morphs of $C$. sigillata are given in Table 3 . The significant difference in mean live weights of the experimental samples was of the same order of magnitude as for field animals (see also Table 1), and the mean temperatures for the onset of freezing (SCP) were significantly different $(P$ $<0.001$ ) for the two morphs, the SCP for the summerdormant animals being almost $4^{\circ} \mathrm{C}$ lower than in winteractive animals. The mean temperature for the onset of melting did not differ between the morphs. More water froze in summer than in winter individuals and this was reflected in the quantities of unfrozen water, $14 \%$ more water remaining unfrozen in the summer morph than in

TABLE 3. Cryobiological parameters of winter-active and summer-dormant morphs of the springtail Ceratophysella sigillata from thermal analyses using Differential Scanning Calorimeter techniques. Water contents are as given in Table 1. OA: osmotically active; free water; OI: osmotically inactive; bound water. Values are mean (SD) in each case.

\begin{tabular}{lccc}
\hline Parameter & $\begin{array}{c}\text { Winter-active } \\
\text { morph }\end{array}$ & $\begin{array}{c}\text { Summer- } \\
\text { dormant morph }\end{array}$ & $\mathrm{P}$ \\
\hline $\mathrm{n}$ & 37 & 38 & \\
Live weight $(\mu \mathrm{g})$ & $64.4(14.4)$ & $13.3(3.8)$ & $<0.001$ \\
Freeze onset & & & \\
$\left({ }^{\circ} \mathrm{C}\right)(\mathrm{SCP})$ & $-12.5(3.2)$ & $-16.2(5.7)$ & $<0.001$ \\
Melt onset $\left({ }^{\circ} \mathrm{C}\right)$ & $-1.3(0.2)$ & $-1.1(0.2)$ & N.S. \\
Frozen water & & & \\
$($ OA) $(\%)$ & $37.0(7.6)$ & $44.0(2.1)$ & $<0.001$ \\
Unfrozen water & & & \\
$($ OI) $(\%)$ & 11.3 & 25.6 & \\
Ratio OI: OA & $1: 3.3$ & $1: 1.7$ & \\
\hline
\end{tabular}

TABLE 4. Mean (SD) values of haemolymph osmolality for melting point (MP), freezing point (FP) and thermal hysteresis (TH) in winter-active and summer-dormant morphs of the springtail Ceratophysella sigillata. Temperature equivalents are also given.

\begin{tabular}{lccc}
\hline Osmolality & MP & FP & TH \\
\hline Winter-active morph & & & \\
mOsm & $222.5(33.2)$ & $307.5(37.5)$ & $85.0(24.1)$ \\
${ }^{\circ} \mathrm{C}$ & $-0.41(0.06)$ & $-0.57(0.07)$ & $0.15(0.04)$ \\
Summer-dormant & & & \\
morph & & & \\
mOsm & $206.3(33.8)$ & $238.3(31.5)$ & $32.0(9.2)$ \\
${ }^{\circ} \mathrm{C}$ & $-0.38(0.06)$ & $-0.44(0.05)$ & $0.05(0.02)$ \\
\hline
\end{tabular}

the winter morph. The resultant ratio of unfrozen (OI) to frozen (OA) water was $1: 3.3$ (winter morph) and $1: 1.7$ (summer morph), supported these findings. Thus OI water constituted $59 \%$ of the total body water during summer compared with only $30 \%$ in winter.

In terms of cold hardiness, all the individuals tested were killed by freezing at their supercooling point temperatures. The supercooling ability of the summer form and the amount of freezable water were greater than in the winter morph, and a larger proportion of the total body water remained unfrozen in the summer morph in these experiments. As a consequence, almost twice the quantity of osmotically inactive (bound) water was present in summer compared with winter individuals.

\section{Thermal hysteresis}

Thermal hysteresis existed in both the winter-active and the summer-dormant morph, being 3 times greater in winter $(P<0.001)$ (Table 4). Haemolymph melting point was not significantly different in the two morphs, being $-0.41^{\circ} \mathrm{C}$ for winter and $-0.38^{\circ} \mathrm{C}$ for summer animals. However, mean haemolymph (or hysteretic) freezing point was significantly $(P<0.001)$ lower in winter-active animals $\left(-0.57^{\circ} \mathrm{C}\right)$ than in summer-dormant individuals $\left(-0.44^{\circ} \mathrm{C}\right)$.

\section{DISCUSSION}

\section{Water relations}

The ratio of unfrozen : frozen water of $1: 3.3$ in the winter-active morph of $C$. sigillata is comparable to values found by Worland (1996) and Worland et al., (1998) for the Arctic springtail Onychiurus arcticus and for other, larger, cold-adapted arthropods (Block et al., 1998; Worland et al., 2000). In contrast, the ratio for summer morphs of $C$. sigillata $(1: 1.7)$ is low compared with several other cold-hardy invertebrates (Table 5), which means that summer-dormant individuals contain a larger proportion of unfrozen water compared to other species. For overwintering freeze-sensitive species, it is conceivable that a smaller quantity of osmotically active water may reduce the potential for lethal freezing. However, cold-hardiness is not a problem during aestivation, so an alternative explanation has to be sought for the low level of water frozen in summer individuals in this population of $C$. sigillata. A possible, highly significant, role 
TABLe 5. Comparison of the ratio of osmotically inactive (unfrozen) to osmotically active (frozen) body water in selected cold hardy invertebrates.

\begin{tabular}{|c|c|c|}
\hline Taxon & $\mathrm{OI}: \mathrm{OA}$ & Reference \\
\hline \multicolumn{3}{|l|}{ Tardigrada: } \\
\hline 2 species & $1: 5-10$ & Westh \& Kristensen (1992) \\
\hline \multicolumn{3}{|l|}{ Nematoda: } \\
\hline Panagrolaimus davidi & $1: 5.5$ & Wharton \& Block (1997) \\
\hline $\begin{array}{l}\text { Globodera rostochiensis } \\
\text { (cysts) }\end{array}$ & $1: 4$ & Wharton \& Worland (2001) \\
\hline \multicolumn{3}{|l|}{ Lumbricidae: } \\
\hline $\begin{array}{l}\text { Dendrobaena octaedra } \\
\text { (cocoons) }\end{array}$ & $1: 6-3$ & Holmstrup \& Westh (1994) \\
\hline \multicolumn{3}{|l|}{ Enchytraeidae: } \\
\hline 6 species & $1: 4-2$ & Block \& Bauer (2000) \\
\hline \multicolumn{3}{|l|}{ Mollusca: } \\
\hline Mytilus edulis & $1: 5$ & Williams (1970) \\
\hline \multicolumn{3}{|l|}{ Collembola: } \\
\hline Onychiurus arcticus & $1: 5-3$ & Worland (1996) \\
\hline Onychiurus arcticus & $1: 7-2$ & Worland et al. (1998) \\
\hline Ceratophysella sigillata & $1: 3-2$ & Present study \\
\hline \multicolumn{3}{|l|}{ Orthoptera: } \\
\hline Hemideina maori & $1: 5.5$ & Ramløv \& Westh (1993) \\
\hline Celatoblatta quinquemaculata & $1: 3$ & Block et al. (1998) \\
\hline \multicolumn{3}{|l|}{ Coleoptera: } \\
\hline Eleodes blanchardi & $1: 4$ & Zachariassen et al. (1979) \\
\hline \multicolumn{3}{|l|}{ Diptera: } \\
\hline Heleomyza borealis larvae & $1: 4$ & Worland et al. (2000) \\
\hline
\end{tabular}

of bound (osmotically inactive) water could be to maintain a basal level of body water in an unfrozen state, which is protected from transpiration losses, and which may be mobilised during periods of extreme drought when free water is in short supply and protect the individual from lethal dehydration. It was found that in experiments with $O$. antarcticus individuals could lose almost all their osmotically active water during desiccation, whereas only a very small amount of the osmotically inactive water was lost (Worland et al., 1998). A similar situation has been reported for cocoons of some species of earthworms, which led to the proposal of a protective dehydration mechanism for cold survival (Holmstrup \& Westh, 1994).

\section{Population ecology}

In the study population of C. sigillata, water is likely to be a limiting factor only during summer. Over ten years of population monitoring, similar distribution patterns were observed: in late winter (March-April), the colonies were distributed throughout the research plot, but in the following December, they reappeared only in the litter layer of the moist part of the plot, which was dominated by spruce; in the beech-dominated, drier areas only a few individuals were found at that time with large colonies being absent (Willisch, 2000). The correlation between soil humidity and colony distribution in December was highly significant $(P<0.001)$. It is suggested that most individuals aestivating in the beech areas die and are replaced by immigration from the adjacent sprucedominated areas in the following February.

Dormant springtails are not immobile, but they are unable to penetrate into the soil deeper than the upper limit of the humus-horizon of the podsolic soil profile, which is dense and highly compacted, so that the available pore spaces are too small for $C$. sigillata to pass through. When active on the surface under favourable humidity conditions in summer the animals are unable to sense the water content of the underlying soil. Migrating individuals move down into the soil either when weather conditions become unfavourable or when an internal clock (or endogenous rhythm) forces the animals to retreat into the soil in preparation for summer dormancy, independent of environmental quality. Thus, during periods of surface activity, colonies cannot select optimal places for aestivation. Therefore insufficient soil moisture during summer drought may cause an ecological bottleneck for dormant individuals. In this context, a physiological mechanism which increases the amount of bound (osmotically inactive) water and thus sustains sufficient body water for survival will be crucial in dry periods in summer. Reduction of cuticular transpiration, in combination with an increase in osmotically inactive (OI) water, may be part of the survival strategy of the summerdormant morph of $C$. sigillata. Alternatively, with a high level of OI water in summer morphs (59\% of total water), even small decreases in the OA water fraction will produce a substantial rise in haemolymph osmolality and with that a decrease in the vapour pressure gradient between the animal and the surrounding air. For example, a loss of $20 \%$ of the total body water content would approximately double the concentration of the haemolymph osmolytes in the OA water compartment (as Collembola do not osmoregulate). In winter individuals, the same loss of body water would only lead to a 1.4-fold increase of the original osmolytes.

\section{Cryobiology}

Individuals of $C$. sigillata had significantly $(P<0.001)$ lower supercooling points (SCP) in summer; their alimentary canals being completely empty as feeding does not occur after moulting into the dormant stage. In winter, the guts of active individuals are $60-90 \%$ full, and when starved, food may be retained in the gut for a considerable time: after $22 \mathrm{~h}$ of starvation, Suter et al. (1993) found $>40 \%$ of the gut remained full of food material. The moderately low SCP of C. sigillata in winter is sufficient to allow activity on the litter or snow surface down to $-2.5^{\circ} \mathrm{C}$ without freezing (Zettel et al., 2002). Below this thermal threshold the springtails retreat into the protection of the litter layer.

Invertebrates in freezing terrestrial conditions are subjected to lower water vapour pressures than in an unfrozen environment. Supercooled terrestrial invertebrates will lose water to the surrounding atmosphere under such conditions (Sømme, 1999). Soil inhabiting freeze-sensitive invertebrates probably dehydrate and equilibrate their body fluid melting points to ambient temperatures in their microhabitats (Holmstrup et al., 2002) 
and do not rely on supercooling for survival overwinter. In the absence of any accumulated polyhydric alcohols and sugars in $C$. sigillata, which would lower the water vapour pressure of the haemolymph in the winter morph, water loss will not be reduced by this mechanism. The difference in body water content of the summer and winter morphs is not due to transpiration losses immediately prior to the experiment. Although, it has been proposed that respiratory transpiration may be of considerable importance to the survival of a wide range of xeric species (Addo-Bediako et al., 2001), this is not the case for Collembola which do not possess spiracles or trachea (except the Sminthuridae).

Lethal freezing is avoided in some earthworm cocoons by a protective dehydration strategy (Holmstrup \& Westh, 1994), and a similar mechanism has been reported in the Arctic collembolan O. arcticus (Worland, 1996; Holmstrup \& Sømme, 1998; Worland et al., 1998). C. sigillata is similar in one respect to $O$. arcticus as osmotically active water is lost during desiccation, but in contrast, the osmotically inactive water component of $C$. sigillata is increased between winter and summer morphs.

\section{Thermal hysteresis}

The role that thermal hysteresis proteins play in Collembola is not fully understood, but they have been detected in several species of drought-resistant arthropods (Duman et al., 1991). It was postulated that thermal hysteresis is important for water retention in Tenebrio molitor larvae (Patterson \& Duman, 1978). Further, Graham et al. (2000) showed that desiccation had the same effect as cold exposure in increasing the level of thermal hysteresis in larvae of T. molitor. THPs were also found in summer-acclimatised oribatid mites (Phauloppia $\mathrm{sp}$.), which were very drought resistant, but had lost up to $90 \%$ of their total body water (Sjursen \& Sømme, 2000). Small, but significant, levels of thermal hysteresis were detected in the winter-active morph $\left(0.15^{\circ} \mathrm{C}\right)$ and in summer-dormant form $\left(0.05^{\circ} \mathrm{C}\right)$ of $C$. sigillata, which would not confer protection from freezing. However, the presence of antifreeze proteins may reduce or prevent ice crystal growth when feeding on frozen algae with associated ice crystals during winter.

Very low levels of thermal hysteresis were measured in C. sigillata. The haemolymph melting point (MP) temperature $\left(-0.41^{\circ} \mathrm{C}\right)$ of $C$. sigillata in winter is higher than subalpine, winter-active Collembola (Isotoma hiemalis, I. propinqua, Agrenia bidenticulata) and higher than hemiedaphic lowland species (Isotoma palustris, Orchesella villosa, Lepidocyrtus cyaneus) (Zettel, 1984). There is no evidence of cryoprotectants being present in winter acclimatised C. sigillata. Lower osmolality produces a lower haemolymph viscosity, which enables a greater degree of mobility at low temperatures. Other winter-active arthropods have distinctly lower MPs: The mecopteran Boreus westwoodi $-1.2^{\circ} \mathrm{C}$, the linyphiid spider Bolyphantes index $-1.4^{\circ} \mathrm{C}$ (Husby \& Zachariassen, 1980). The haemolymph freezing point (FP) $\left(-0.57^{\circ} \mathrm{C}\right)$ of C. sigillata during winter is higher than in subalpine, winter-active Collembola (species as above), whilst its summer haemolymph
FP $\left(-0.44^{\circ} \mathrm{C}\right)$ is similar to these litter-dwelling species. In comparison to lowland species, winter values of both haemolymph MP and FP are higher in C. sigillata, whereas summer values are similar. Three species of subAntarctic Collembola showed no detectable thermal hysteresis (Sinclair \& Chown, 2002), whereas a maximum thermal hysteresis of $1.1^{\circ} \mathrm{C}$ was reported for the Antarctic springtail Gomphiocephalus hodgsoni (Sinclair \& Sjursen, 2001).

Thermal hysteresis (TH) has not been observed in edaphic species of Collembola which have no winter activity on the snow surface. In winter, the TH of C. sigillata haemolymph is $10 \times$ smaller than in subalpine winteractive species such as $I$. hiemalis, $I$. propinqua and $A$. bidenticulata, which exhibit similar cold avoidance behaviour, retreating into the snow pack when the surface temperature reaches c. $-3^{\circ} \mathrm{C}$. In summer, the $\mathrm{TH}$ of $C$. sigillata haemolymph $\left(0.05^{\circ} \mathrm{C}\right)$ is higher than, for example, than that of $I$. hiemalis $\left(0.012^{\circ} \mathrm{C}\right)$. TH values for $B$. index $\left(5.2^{\circ} \mathrm{C}\right)$ and $B$. westwoodi $\left(5.4^{\circ} \mathrm{C}\right)$ are much greater than in Collembola, which have been studied (Husby \& Zachariassen, 1980). Summer TH levels in C. sigillata are comparable to those of Entomobrya nivalis $\left(0.06^{\circ} \mathrm{C}\right.$; Zettel, 1984), which remains on spruce tree bark and endures significant periods of drought. Although thermal hysteresis appears to be important for water retention in larval Tenebrio molitor under dry conditions, where up to $6{ }^{\circ} \mathrm{C}$ have been recorded (Patterson \& Duman, 1978), it is unlikely that such a small amount $\left(0.15^{\circ} \mathrm{C}\right)$ of thermal hysteresis will have a significant influence on water conservation in C. sigillata.

\section{Survival}

These results have implications for the population ecology of $C$. sigillata. Winter activity at low environmental temperatures appears to present less of a problem for the survival of this population of $C$. sigillata than summer drought. With a well-developed supercooling ability $\left(\mathrm{SCP}-12.5^{\circ} \mathrm{C}\right.$ ) and a small, but significant, level of thermal hysteresis, the species is able to feed and migrate considerable distances, only retreating into deeper layers of the forest floor when surface temperatures decline below $-2.5^{\circ} \mathrm{C}$. Feeding at low temperatures does not compromise individual survival: winter-adapted algae significantly increase the cold hardiness of $C$. sigillata, when ingested, compared with non-adapted algae or starved control animals (Zettel et al., 2002). Ingestion of ice crystals with food during winter will pose a considerable risk of freezing via inoculation and thermal hystereis proteins may protect individuals by reducing or preventing ice crystal growth. Recent results (Zettel et al, 2002) suggest that algal antifreezes are sequestrated by springtails during winter, thereby improving their cold tolerance.

The regular extinction of colonies in this springtail population in the beech-dominated part of the study site is brought about by summer aridity in the forest floor habitat, which causes an ecological bottleneck. In addition, there may be a stress synergy between drought and common environmental contaminants (e.g. agricultural 
pollutants), which could significantly alter its drought tolerance as has been found for the springtail Folsomia candida (Højer et al., 2001). The results of the present study suggest that the ecophysiological mechanism, which operates to retain sufficient body water to survive drought, is based upon the transfer of part of the freezable (osmotically active) water to the bound (osmotically inactive) water compartment in C. sigillata.

It is concluded that the survival of such a winter-active collembolan is not jeopardised by its unusual life cycle as it possesses well developed physiological mechanisms to overcome the problems presented by winter activity in freezing conditions and by being dormant during aestivation in summer drought.

ACKNOWLEDGEMENTS. The support of the British Antarctic Survey and the University of Bern in the form of research facilities and travel funds is gratefully acknowledged. The assistance of Rebecca Martin with data input was invaluable. The ms has benefited from the comments of several colleagues in cryobiology and ecophysiology, and from three reviewers.

\section{REFERENCES}

Addo-Bediako A., Chown S.L. \& Gaston K.J. 2001: Revisiting water loss in insects: a large scale view. J. Insect Physiol. 47: $1377-1388$

Bedos A. \& Cassagnou P. 1988: La réalisation de l'écomorphose chez Hypogastrura boldorii (Collembole) à la tourbière du Pinet (Aude). Rev. Écol. Biol. Sol 25: 315-331.

BLocK W. 1994: Differential scanning calorimetry in ecophysiological research. Acta Oecol. 15: 13-22.

BLock W. 2002: Interactions of water, ice nucleators and desiccation in invertebrate cold survival. Eur. J. Entomol. 99: 259-266.

BLock W. 2003: Water or ice? - the challenge for invertebrate cold survival. Science Progress 86: 77-102.

Block W. \& BAUER R. 2000: DSC studies of freezing in terrestrial enchytraeids (Annelida: Oligochaeta). CryoLetters 21: 99-106.

Block W., Wharton D.A. \& Sinclair B.J. 1998: Cold tolerance of a New Zealand alpine cockroach, Celatoblatta quinquemaculata (Dictyoptera: Blattidae). Physiol. Entomol. 23: 1-6.

Cassagnou P. \& Laugra-Reyrel F. 1992: Sur le polymorphisme et le cycle sexuel du Collembole Superodontella lamellifera (Axelson) dans les Pyrénées. Annls Soc. Entomol. Fr. (NS) 28: $371-384$

DUMAN J.G. 1977: The role of macromolecular antifreeze in the darkling beetle Meracantha contracta. J. Comp. Physiol. 115 279-286.

Duman J.G., Xu L, Neven L.G., Tursman D. \& Wu D.W. 1991 Hemolymph proteins involved in insect sub-zero temperature tolerance: ice nucleators and antifreeze proteins. In: Lee R.E. \& Denlinger D.L. (eds): Insects at Low Temperature. Chapman \& Hall, New York, pp. 94-127.

FrANKS F. 1986: Unfrozen water: yes; unfreezable water: hardly; bound water: certainly not. An editorial note. CryoLetters 7: 207.

Graham L.A., Walker V.K. \& Davis P.L. 2000: Developmental and environmental regulation of antifreeze proteins in the mealworm Tenebrio molitor. Eur. J. Biochem. 267: 6452-6458.

HÅGVAR S. 1995: Long distance, directional migration on snow in a forest collembolan, Hypogastrura socialis (Uzel). Acta Zool. Fenn. 196: 200-205.
Holmstrup M. \& Westh P. 1994: Dehydration of earthworm cocoons exposed to cold: a novel cold hardiness mechanism. J. Comp. Physiol. B 164: 312-315.

Holmstrup M. \& SøMme L. 1998: Dehydration and cold hardiness in the arctic collembolan Onychiurus arcticus Tullberg 1976. J. Comp. Physiol. B 168: 197-203.

Holmstrup M., Bayley, M. \& Ramløv H. 2002: Supercool or dehydrate? An experimental analysis of overwintering strategies in small permeable Arctic invertebrates. Proc. Natn. Acad. Sci. U.S.A. 99: 5716-5720.

Højer R., Bayley M., Damgaard C.F. \& Holmstrup M. 2001: Stress synergy between drought and a common environmental contaminant: studies with the collembolan Folsomia candida. Global Change Biol. 7: 485-494.

Husby J.A. \& ZACHARIASSEN K.E. 1980: Antifreeze agents in the body fluid of winter active insects and spiders. Experientia 36: 963-964.

Patterson J.L. \& Duman J.G. 1978: The role of the thermal hysteresis factor in Tenebrio molitor larvae. J. Exp. Biol. 74: $37-45$.

RamløV H. \& WeSth P. 1993: Ice formation in the freeze-tolerant alpine weta Hemideina maori Hutton (Orthoptera: Stenopelmatidae). CryoLetters 14: 169-176.

Sinclatr B.J. \& ChOWN S.L. 2002: Haemolymph osmolality and thermal hysteresis activity in 17 species of arthropods from sub-Antarctic Marion Island. Pol. Biol. 25: 928-933.

Sinclatr B.J. \& SJursen H. 2001: Cold tolerance of the Antarctic springtail Gomphiocephalus hodgsoni (Collembola, Hypogastruridae). Antarctic Science 13: 271-279.

SuURSen H. \& Sømme L. 2000: Seasonal changes in tolerance to cold and desiccation in Phauloppia sp. (Acari: Oribatida) from Finse, Norway. J. Insect Physiol. 46: 1387-1396.

Suter C., Zettel J. \& Zettel U. 1993: Nahrungsökologie der winteraktiven Collembolenart Ceratophysella sigillata (Hypogastruridae). Rev. Suisse Zool. 100: 805.

SøMme L. 1999: The physiology of cold hardiness in terrestrial arthropods. Eur. J. Entomol. 96: 1-10.

UChidA H. \& Füita K. 1968: Mass occurrence and diurnal activity of Dicyrtomina rufescens (Collembola: Dicyrtomidae) in winter. Sci. Rep. Hirosaki Univ. 15: 36-48.

WESTH P. \& KRISTENSEN R.M. 1992: Ice formation in the freeze-tolerant eutardigrades Adorybiotus corinifer and Amphibolus nebulosus studied by differential scanning calorimetry. Pol. Biol. 12: 693-699.

WhARTON D.A. \& BLock W. 1997: Differential scanning calorimetry studies on an Antarctic nematode (Panagrolaimus davidi) which survives intracellular freezing. Cryobiology 34 : 114-121.

WHARTON D.A. \& WORLAND M.R. 2001: Water relations during desiccation of cysts of the potato-cyst nematode Globodera rostochiensis. J. Comp. Physiol. B 171: 121-126.

Williams R.J. 1970: Freezing tolerance in Mytilus edulis. Comp. Biochem. Physiol. 35: 145-161.

Williscr C. 2000: Dichte- und Altersverteilung der oberflächenaktiven Form von Ceratophysella sigillata im Dezember. Res. Rep., Zool. Inst. Univ. Bern, 26 pp.

WORLAND M.R. 1996: The relationship between water content and cold tolerance in the Arctic collembolan Onychiurus arcticus (Collembola: Onychiuridae). Eur. J. Entomol. 93: 341-348.

Worland M.R., Block W. \& GRubor-Lajsic G. 2000: Survival of Heleomyza borealis (Diptera, Heleomyzidae) larvae down to $-60^{\circ}$ C. Physiol. Entomol. 25 : 1-5.

Worland M.R., Grubor-Lajsic G. \& Montiel P.O. 1998: Partial desiccation induced by sub-zero temperatures as a compo- 
nent of the survival strategy of the Arctic collembolan Onychiurus arcticus (Tullberg). J. Insect Physiol. 44: 211-219.

Zachariassen K.E., Hammel H.T. \& Schmidek W. 1979 Osmotically inactive water in relation to freezing in Eleodes blanchardi beetles. Comp. Biochem. Physiol. A 63: 203-206.

ZetтeL J. 1984: Cold hardiness strategies and thermal hysteresis in Collembola. Rev. Écol. Biol. Sol 21: 189-203.

Zettel J. 1999: Alpine Collembola - adaptations and strategies for survival in harsh environments. Zoology 102: 73-89.

Zettel J. \& Zettel U. 1994a: Development, phenology and surface activity of Ceratophysella sigillata (Uzel) (Collembola: Hypogastruridae). Acta Zool. Fenn. 195: 150-153.

ZetTel U. \& ZetTel J. 1994b: Seasonal and reproductional polymorphism in Ceratophysella sigillata (Uzel) (Collembola: Hypogastruridae). Acta Zool. Fenn. 195: 154-156.
Zettel J. \& Zettel U. 1996: Manche mögen's kalt - zur Biologie von Ceratophysella sigillata (Collembola, Hypogastruridae). Mitt. Entomol. Ges. Schweiz 69: 286.

Zettel J., Zettel U. \& EgGer B. 2000: Jumping technique and climbing behaviour of the collembolan Ceratophysella sigillata (Collembola: Hypogastruridae). Eur. J. Entomol. 97: $41-45$.

Zettel J., Zettel U. \& Ryser A. 1997: Surface activity in Ceratophysella sigillata (Collembola: Hypogastruridae) and the influence of climatic parameters. Rev. Suisse Zool. 104: 725.

Zettel J., Zettel U., Suter C., Streich S. \& Egger B. 2002; Winter feeding behaviour of Ceratophysella sigillata (Collembola: Hypogastruridae) and the significance of eversible vesicles for resource utilisation. Pedobiologia 46: 404-413.

Received October 15, 2002; revised January 6, 2003; accepted January 6, 2003 